\title{
POPULATION GROWTH AND BOTTLENECKS IN PROVISION OF QUALITATIVE PUBLIC INFRASTRUCTURE SERVICES IN THANE MUNICIPAL CORPORATION
}

\author{
Sanjay RODE \\ Department of Economics, S.K.Somaiya College, Somaiya University, India \\ Sanjay.rode@somaiya.edu
}

\begin{abstract}
Every municipal corporation must provide civic services to its population. Since liberalization period, the population and urbanization has increased very fast in Thane city. The density of population is continuously increasing due to growth of industries, services sector and clean environment in city. The commercial and residential complexes, Theaters, private parks, super specialty hospitals, Mall, educational institutions have grown significantly over the period. However, the quality of infrastructure services such as water supply, sewage collection and disposal, health services, water drainage, transportation, park and recreation are still inadequate to rising population in Thane Municipal Corporation area. Therefore, Municipal Corporation should increase its revenue sources through bond financing. Urban planning must be done in a systematic way and on urgent basis for entire corporation area. Municipal Corporation must provide quality services to its population. Municipal Corporation must invest financial resources for welfare of poor people and future planned economic growth of Thane city.
\end{abstract}

Keywords: Health, Sanitation, Water supply, Nutrition.

\section{INTRODUCTION}

All over world, migration of people is taking place from rural to urban areas. In developing counties, urbanization is taking place at large scale. After independence, Government of India promoted industrialization in selected areas in country. The Maharashtra Government also promoted industrialization in Thane district. Many big and small industrial units were provided land at very lower rate by state government in urban Thane. Such industries created skilled and unskilled employment. Therefore, large-scale migration took place in city from within state and outside of state. The different types of industries were provided land by state government at concessional rate. Lower standard of living, high population density and easy availability of cheap labor force have together demanded various facilities and services in urban areas (Ghosh and Kalra, 2016). 
Over the period, the development of city took place without any urban or city development plan. People started living in slums and nearby pipelines, below high-tension wires, streets, on top of mountain etc. For Municipal Corporation, it was not possible to provide various infrastructural facilities including housing to scattered population. Rapid urbanization is facing a massive pressure on its land and the city was trying to meet the demand by initiating encroachment of water bodies, unplanned development and the wetlands grabbing (Subrina and Chowdhury, 2018).

The municipal authority allowed more migration and high density of population. The rich people found affordable housing in Thane as compare to Mumbai city. But over the period of time, an interaction between space and time is well documented in the study of urban sprawl. An expansion of urban margins becomes the outcome of changing functionality of space within the given time frame. While urban sprawl becomes inevitable phenomena (Guite, 2017).

Thane city went under various phases of industrialization. In liberalization period, most of the industries were producing and exporting various products. They were providing maximum employment to different types of skilled and unskilled people. Thane city was called as industrial city until last decade. Many small industrial units were converted into large-scale units with more employment capacity. It was difficult for large units to manage latest technology, fashion, and labor skills. After globalization, most of the industrialist found difficulty in overall production and management. The major problems in globalization period were union strikes, cost of production and land value, wages of skilled and unskilled staff and market for products. Most of the industries declared as sick industries and closed production. The industrial owners saw more profit in sale of land rather than continue production and manufacturing activities. Due to growth of population, there was more demand for housing. The industrial units were declared sick. The land was later sold to builders at lower price. Builders build housing projects for rich people in city. The People in corporation area continuously demanding qualitative infrastructure facilities such as drinking water, sanitation, sewage treatment and educational institutions, transport, solid waste collection. Municipal Corporation was providing various civic infrastructure facilities, but it was not possible to cover entire population. The Municipal Corporation is providing qualitative civic infrastructure facilities in few developing areas.

Over the period, rainwater drainage in city is not properly built. Different parts of various wards population in slums has increased. Municipal Corporation does not have planning to develop drainage system. As population increases, every year Municipal Corporation tries to expand the drainage network. Since many decades, the drainage system is not properly planned and constructed for city. The water flow is not checked before rainy seasons. It further resulted into flooding at various areas in rainy seasons of city. Therefore, every year flooding observed due to unscientific way of drainage lines. Inadequate drainage system is major issue for flooding in Thane city. The water flooding mainly 
Rode, $\mathrm{S}$.

POPULATION GROWTH AND BOTTLENECKS IN PROVISION OF QUALITATIVE PUBLIC INFRASTRUCTURE SERVICES IN THANE MUNICIPAL CORPORATION

damages the property and many people die in flooding every year. The city stops functioning for few hours every year in June and July. It causes an in-convenience to vehicles and people's movement in city. Municipal Corporation has not reserved open spaces for people in city. People do not find the big public parks, gardens in city. Urbanization has grown very fast in short period in city. People often find overcrowding and encroachment at existing park and recreation facilities. Thane city is stressed due to transportation issues. The stress manifests are observed by both external and internal factors. External stress is the on-road congestion and internal congestion is the overcrowding of people within the public transport vehicle. The deterioration of urban transport systems occurs due to lack of dedicated funding available to TMC to improve its level of service (Varghesea and Bhargav, 2016). Municipal Corporation is providing the transportation facilities through corporation buses to its population. The corporation buses are not maintained and in good condition. The frequency of buses is very low, and they are inadequate for rising population. The Thane Municipal Corporation does not want to increase the corporation buses due to various reasons. The smaller number of buses on roads are affecting on commuter's time and traveling comfort. They often travel by auto rickshaw by paying more money for short distance. The rich people can afford to travel by private vehicles or different alternative mode of transport. But the poor are always depending on the public transport facility in Thane city. The public transport system is ineffectively and inefficiently since many decades in city. Therefore, the city transport system is not earning any profit. The municipal transport system is always treated as burden on the corporation. The old buses are allowed to transport people and they fail to complete scheduled trips. The roads are not in proper condition and there is huge traffic observed in city. The people do not want to pay more for municipal transport facility. An entire public transport system in corporation area is not functioning sustainability. Overcrowding in city buses is a direct reflection of the poor quality of service. The cost of travel and time factors are not taken consideration by transport department (Varghesea and Bhargav, 2016).

Municipal Corporation provides drinking water to its people. But the access to drinking water is inadequate, irregular and low in quality. The drinking water to kutcha slums is not provided at all. The poor people are struggling to get the minimum quality of drinking water in city. The women children and older people of households are carrying the drinking water. Whenever there is repairing of pipeline, upgradation and joining new pipeline work, there is no water in different parts of city. During such period alternative water supply is not arranged. Poor people have no choice but to limit the water use for different purposes. The ground water quality in city is not good. Due to industrialization and excessive urbanization, the ground water quality has deteriorated. People have no choice but to buy pure water from water venders. An overwhelming amount of solid waste is generated every year in city due to an 
increased population and change in lifestyle. There are three types of solid waste as general municipal solid waste, electronic waste and household waste and they are posing greater challenge to segregate (Baidya et al., 2016). Management of daily solid waste is a major challenge in Thane city. Due to the lack of effective management programs, regulations, and policies; waste is causing sever health hazards including several communicable diseases, bad odors, nuisance, and environmental impacts, such as, water pollution, soil pollution, and air pollution, if the waste is burnt in an uncontrolled manner (Verma et al., 2016). The solid waste is not collected all over city. Most of the households do not segregate wet and dry solid waste. Municipal Corporation collects solid waste at few places. Many poor people thrown solid waste in open ground, sewage lines or in ponds. The solid waste is generated in more quantity because high income of maximum population and people's behavior about cleanliness. The complete solid waste is not collected every day all over city. Garbage treatment in households offers the opportunity to eliminate the inconvenience of extended waste management systems. At a domestic level several waste management systems may be applied depending on available space, time, and the financial resources of the householders. Unfortunately, no efforts are done in complete collection of solid waste in city. Various techniques and equipment's are available; from the cheapest home-made boxes to complex but relatively expensive automatic composters. But they are not applied in city (Jouhara et al., 2017). The health care services in Thane city are provided by only two municipal hospitals. The health care services provided in city is inadequate, inconsistent. The quality of services is very poor. There are always long queues for the health care services provided at public health care hospitals in corporation. The doctors and nurses and other supporting staff are not appointed on regular basis. The medical equipment's which required for health care facilities are not available. The doctors and nurses are not paid adequate remuneration. Due to overcrowding at health facility people spent more time in queue and repetitive visits could not possible. The poor women and children are affecting the most because they cannot afford to wait in long queue and visit repeatedly for health care facilities. The first objective of this paper is to understand the various budgets of the Thane municipal corporations. Second, important objective of study is to find the growth rate of revenue receipts and capital receipts as well as revenue expenditure and capital expenditure. Third objective is to find the gap between them. The last objective is to find the alternative sources to finance the budget deficit. The first part of paper related to the data and methodology. The second part deals with revenue as well as capital receipts and expenditure. Second last part of paper explains about the regression result and lastly it deals with policy implication and conclusion. 


\section{LITERATURE REVIEW}

Municipal Corporations are important for provision of quality public infrastructure services and improve the standard of living of people. There are few studies focused on the services provided by the different municipal corporations. The basic role of public finance is to provide 'public goods' which markets fail to provide. In addition, the government is requited to ensure optimal provision of services with significant generalized externalities which are called merit goods (Govinda Rao, 2017). The three-tier structure of the Indian Government i.e. Union, State \& Local Self Government is the scenario of the Indian constitution. Local Self Government performs or renders many services under the direct control of state government. They (local bodies) possess autonomy within its limited sphere, raise revenue through local taxation \& spend its income on local services. The researcher has taken the prime body of the local self-government viz. Municipal Corporation. However, the number of municipal corporations in India has rapidly increased in recent years. People are moving very fast from rural area to urban area. Their demand, awareness is increasing day by day. The Municipal Corporations render many services for the development of the urban area (Nena, 2014). Few authors have argued about the concentration of power with the help of fiscal federalism. Decentralization increases efficiency of the lower levels of Government in the provision of various local services due to their limited jurisdiction and better matching of services. An increase in decentralization is expected to delegate more powers to local government authorities and augment their capacity to mobilize resources. The government should reorient its attitude regarding municipal corporations, providing constructive guidance and adequate assistance to them as an active partner to the common cause of city administration (Siddaram and Bharadi, 2017). With many projects and policies now aimed at municipal level, availability of finance to the local bodies becomes crucial. With programs initiated at the central level and aimed at the city, grant is more accessible. Formation of local self-government is also a state subject, which means the criteria to form a municipal government rest with the state government and if the municipality is within a metropolitan area, the state government's influence is doubled (Khatua, 2019). Quality of public finances belongs to a key policy challenge as its improvement should lead to a long-term economic growth (Szarowská, 2016). Above studies do not analyze different budgets of municipal corporations. These studies failed to provide the answer as how municipal corporations will provide various services to rising population. There is no planning in revenue collection and expenditure. Municipal corporations do not prepare regular development plans. There are no alternative methods to finance revenue and capital expenditure. The present study is focusing on all the above issues and trying to provide the solutions for longer period. 


\section{DATA}

We collected primary and secondary data from various sources. The secondary data for this study is mainly collected from the Thane Municipal Corporation budgets. The budgets of Municipal corporation are available from 2008-2019. The budgets clearly provide the revenue and capital receipts and expenditure over the period of time. We have collected population growth data from 1971, 1981, 1991, 2001 and 2011 census reports. Small fraction of secondary data for this study is collected from books and research articles. There are various studies by financial institutions and banks related to finances of Thane Municipal Corporation in the past. Regular visits to Thane city conducted since many years. Few observations related to traffic, public transport, sewage management, slums, water supply and sewage done over the period. We have analyzed this data in SPSS@24 and STATA @11 software.

\section{ECONOMETRIC METHODOLOGY}

The public finance related scholars have applied different statistical techniques to study the municipal corporations' data. The municipal corporations of Thane's revenue and capital receipts and expenditure is considered in this study. An annual compound growth method is found more suitable for budget analysis of corporation. Such compound growth rate is explained as follows,

$$
Y_{i t}=a * b^{t}
$$

Here $Y_{\text {it }}$ means the estimated income or expenditure of Municipal Corporation in ith component for $t$ period. We have considered the period from 2008-09 to 2018-19. Similarly, a and b in equation (1) are considered as parameters to be estimated for study. We can further write above equation (1) in simple form as follows.

$$
\log Y_{i t}=\log a+T \log b+\log u_{i t}
$$

We can see here that log is taken for estimated Municipal Corporation's income over the period. The compound growth rate $(\mathrm{g})$ can be estimated by the identity given in the following equation.

$$
G=(\hat{b}-1) \times(100)
$$

The $g$ in above equation explains calculated compound growth for 2008-2019 data series. We have further explained in percent form for each subhead of all budgets. We can further derive the parameter as follows.

$\hat{B}=A n t i \log b$ 
Rode, $\mathrm{S}$.

POPULATION GROWTH AND BOTTLENECKS IN PROVISION OF QUALITATIVE PUBLIC INFRASTRUCTURE SERVICES IN THANE MUNICIPAL CORPORATION

Above percent is presented as revenue and capital receipts and expenditure with subheads of Thane Municipal Corporation budgets (2008-2019. We can see the sub content and percent with each category from the different tables.

\section{BUDGET CONSTRAINT FOR THANE MUNICIPAL CORPORATION}

The budget constraint for the corporation is explained as follows.

$\sum_{t=n}^{t=1} B_{s d}=(T R R-T R E)-(T C R-T C E)$

Where

The budget surplus or deficit $\left(\mathrm{B}_{\mathrm{sd}}\right)$ of Municipal Corporation in $\mathrm{ith}^{\text {th }}$ period at time $\mathrm{t}$ is important aspect for budget analysis. The TRR it is Total Revenue Receipts at ith period during time t. The TRE is total revenue Expenditure in $\mathrm{i}^{\text {th }}$ period at time t. The TCR is Capital Receipts in $\mathrm{i}^{\text {th }}$ period at time t. At the last, TCE is Capital Expenditure for municipal corporation during period $i^{\text {th }}$ with time $t$.

$\sum_{t=n}^{t=1} T R R=(P R+P W+H+S W M+C A+P A S W+R)$

Where

PR in above equation means Planning and Regulation receipts, PW defined as receipts from Public Work. $\mathrm{H}$ is defined as Health department receipts. The SWM means receipts of Solid Waste Management CA: Civic Amenities related receipts PASW: Poverty Alleviation and Social Workrelated receipts $R$ : Revenue receipts from different sources

$\sum_{t=n}^{t=1} T R E=(G A+P W+C A+S+O S)$

Where

GA means General Administration expenses. The PW defined as Public Works expenses of corporation. CA is Civic Amenities expenditure of corporation. The $S$ is defined as Sanitation. The OS simply means Other Services expenses of corporation.

$\sum_{t=n}^{t=1} T C R=(W S+H+R+S W)$

Where:

The capital receipts of corporation is defined as follows. The WS is Water Supply related receipts of corporation. The capital receipts from health department is defined as Health $(H)$. The capital receipts are $\mathrm{R}$ and Roads. The SW is defined as capita receipts from Solid Waste. 
$\sum_{t=n}^{t=1} T C E=(G A+P R+P W+H+S W M+C A+S W+O S)$

Where,

The capital expenditure defined as GA means General expenditure. The PR is planning, and Regulations related capital expenditure. The PW means Public Works receipts. The $\mathrm{H}$ means Health related receipts. The SWM is receipts from Solid Waste Management. The capital receipts defined Civic Amenities (CA). The SW is Social Welfare related receipts and lastly OS means Other Services.

\subsection{Revenue receipts of Thane Municipal Corporation}

We have analyzed the Thane Municipal Corporations revenue receipts from 2008-1019. The receipts are explained in detail as follows.

TABLE 1. REVENUE RECEIPTS OF THE MUNICIPAL CORPORATION (2008-2019)

\begin{tabular}{|c|c|c|c|}
\hline No & Categories & Contents & Percent \\
\hline \multirow{7}{*}{1} & \multirow{7}{*}{ Planning and regulation } & Land and building tax & 13.04 \\
\hline & & Octri & 16.79 \\
\hline & & Advertisement section & 18.29 \\
\hline & & Property tax & 26.77 \\
\hline & & Encroachment removal & 20.59 \\
\hline & & Permission and regulation & 18.97 \\
\hline & & City development & 15.54 \\
\hline 2 & Public work & Public work department & 19.30 \\
\hline \multirow{4}{*}{3} & \multirow{4}{*}{ Health } & Health department & 9.69 \\
\hline & & Birth and death department & 6.22 \\
\hline & & Medical education & 17.14 \\
\hline & & CSM Hospital & 5.95 \\
\hline \multirow[b]{3}{*}{4} & \multirow{3}{*}{$\begin{array}{l}\text { Sanitation and solid } \\
\text { waste management }\end{array}$} & Solid waste management & 9.69 \\
\hline & & Cattle ponding & -2.09 \\
\hline & & Slaughterhouse & 0.04 \\
\hline \multirow{4}{*}{5} & \multirow{4}{*}{ Civic amenities } & Fire work department & -10.86 \\
\hline & & Theatre & 13.49 \\
\hline & & Stadium & -8.24 \\
\hline & & Lakes and ponds & -4.55 \\
\hline 6 & $\begin{array}{l}\text { Poverty alleviation and } \\
\text { social welfare }\end{array}$ & Social development & 19.55 \\
\hline 7 & Revenue & Tax collection department & 9.92 \\
\hline
\end{tabular}

Source: Estimated from Thane Municipal Corporation budgets

Land tax comprises tax related to building, road tax, education and empty land tax for Municipal Corporation. Land and building tax have grown as 13.04 per cent from 2000-2019. The octroi was 16.79 per cent from 2008-19. It mainly includes service tax, refunds, deposits, penalty tax, administrative tax and refund from government to Municipal Corporation. The advertisement section contributes 18.29 per 
Rode, $\mathrm{S}$.

POPULATION GROWTH AND BOTTLENECKS IN PROVISION OF QUALITATIVE PUBLIC INFRASTRUCTURE SERVICES IN THANE MUNICIPAL CORPORATION

cent of CAGR for Municipal Corporation. The municipal corporation collects fees from various advertisements in area. There are many illegal hoardings observed in Thane city. The municipal corporation puts penalty on such illegal hoarding and advertisement in corporation area. Municipal Corporation also collects the show taxes which are taking place in city. The municipal corporation collects the school rent in corporation area. The property tax is observed as 26.77 per cent from 200819. The temporary land rent and property tax is collected regularly in corporation. The Municipal Corporation also gets the rent from commercial properties. Municipal Corporation also gets the rent from the rental housing scheme of corporation area.

The revenue receipts from encroachment removal were 20.59 per cent. The municipal corporation charges fines on encroachment on corporation land. The Municipal Corporation has properties and land at various places. The municipal corporation put fines on illegal construction. Due to high density in corporation area, the vehicles are parked at various places. The illegal parking is charged very heavily by traffic police. Thane Municipal Corporation collects high amount as license fees and identity cards for hawkers and their encroachments on streets. The permission and regulation were 18.97 per cent. The municipal corporation charges the fees for various permissions in corporation area. It includes various permission for small scale companies, shops, bars and other commercial business. They regularly apply for various licenses and permissions for different types of business in city. The city development receipts were grown with 15.54 per cent. The receipts from public work department have grown with 19.30 per cent. The revenue receipts of health department were 9.69 per cent. The Municipal Corporation hospitals charge patients fees and various test fees in hospitals. The corporation also charge license and permission fees from private hospital in corporation area. The municipal corporation charges the insect prohibition fees. An ambulance fees is charged by the corporation. The receipts from birth and death department were 6.22 per cent. Municipal Corporation charges birth and death certificates fees. The stationary related to certificates are also sold by corporation where birth and death department gets some revenue. The medical education related receipts were 17.14 per cent. Municipal Corporation gets revenue from the RGMC fees. The revenue also received from nurse training institute. The receipts from CSM hospital was 5.95 per cent. The municipal corporation gets the fees from patients. The growth of receipts to solid waste management was 9.69 per cent. Municipal Corporation charges service fees for solid waste collection. Municipal Corporation collects dead animals and charge fees for that. The revenue receipts from the cattle ponding was -2.09 per cent. The municipal corporation collect fodder fees and the ponding administrate fees. But over the period of time, it has declined. The revenue receipts from slaughterhouses were 0.04 per cent. Slaughterhouse fees includes the market fees and slaughterhouse fees. The municipal corporation also charge slaughterhouse 
administrative fees. The corporation also charges the domestic dog license fees. The permission fees are charges for the domestic dogs at home.

As far as civic amenities are concerned then revenue receipts from fire work department was -10.86 per cent. There are different certificates are given. The rent fess is collected. The municipal corporation collect the fire service fees. The fire permission charges are put by corporation. The fire infrastructure is charges are there for corporation. The revenue receipts from the theaters were 13.49 per cent. The municipal corporation charges the club house member fees. The canteen fees rent is charged. The theatre and Jim fees are also charged. The mini theaters rent is charged by corporation. The revenue receipt from Dadoji Kondadeo Stadium was -8.24 per cent. The Ram Ganesh Gadkari theatre, canteen fees are the revenue receipts for corporation. At the same time, the Kashinath Ghanekar theatre rent is also revenue receipts for corporation. The revenue receipts from lakes and ponds were -4.55 per cent. Municipal Corporation charges the fees from Marotrao Shinde Lake, the swimming pool fees also charged. The Prabhodankar Thakare swimming fees is also charged by corporation. As per as poverty alleviation and social welfare is concerned then social development is concerned then it was 19.15 per cent. The social development includes the fees charged for identity card. The slum rent and the administrative fees are also charged by the corporation. The service tax is also collected every year by the Thane Municipal Corporation. The transfer of rent is also done by corporation itself. The notice fees are also charged by corporation. The revenue receipts for Municipal Corporation are concerned then growth for tax collection department was 9.92 per cent. The municipal corporation is also charge fees as transfer fees, other fees and administrative fees. The corporation also collects the illegal construction fees and transfer.

\subsection{Revenue expenditure of Thane Municipal Corporation}

We have studied the municipal corporation's revenue expenditure from 2008-2019. The results are presented in the following table.

TABLE 2. REVENUE EXPENDITURE OF MUNICIPAL CORPORATION

\begin{tabular}{|c|c|c|c|}
\hline No & Items & Details & Percent \\
\hline \multirow{4}{*}{1} & General & Office expenses & 9.20 \\
\cline { 3 - 4 } & administration & Stationary & 8.26 \\
\cline { 3 - 4 } 2 & \multirow{3}{*}{2} & Vehicles & 14.14 \\
\cline { 3 - 4 } & \multirow{3}{*}{ Public works } & Wireless machinery & 10.78 \\
\cline { 3 - 4 } & & Telephone related expenditure & 1.18 \\
\cline { 3 - 4 } & & Vehicle expenses & 9.85 \\
\cline { 3 - 4 } 3 & \multirow{2}{*}{ Civic amenities } & Automation & 57.38 \\
\cline { 3 - 4 } & & Water supply & 13.50 \\
\cline { 3 - 4 } & & Water supply by tankers & -4.91 \\
\cline { 3 - 4 } & & Pumping machinery & 46.07 \\
\hline
\end{tabular}


Rode, S.

POPULATION GROWTH AND BOTTLENECKS IN PROVISION OF QUALITATIVE PUBLIC INFRASTRUCTURE SERVICES IN THANE MUNICIPAL CORPORATION

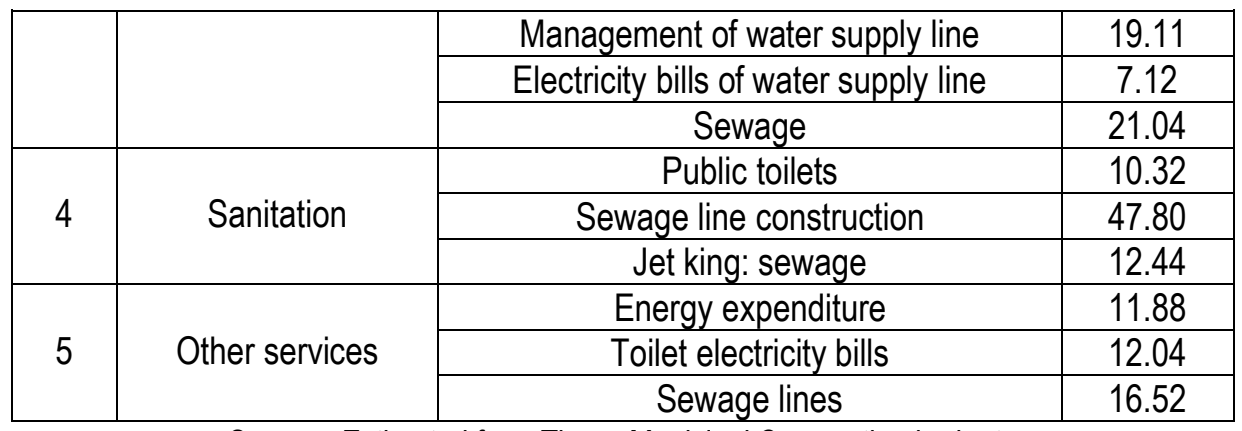

Source: Estimated from Thane Municipal Corporation budgets

The revenue expenditure on office expenses was 9.20 per cent. The revenue expenditure on stationary was 8.26 per cent. Expenditure on vehicles was 14.14 per cent. The public works is concerned then wireless machinery expenses was 10.78 per cent. The revenue expenditure on telephone was only 1.18 per cent. The vehicle expenses were 9.85 per cent. The automation related revenue expenditure was 57.36 per cent. Civic amenities: revenue expenditure on water supply was 13.50 per cent. The revenue expenditure on water supply by tanker is -4.19 per cent. The revenue expenditure on pumping machinery was 46.07 per cent. The water supply line revenue expenditure on water supply line management was 19.11 per cent. The revenue expenditure on electricity bill of water supply shown as 7.12 per cent. The revenue expenditure on sewage line was 21.04 per cent. The revenue expenditure on public toilet is observed as 10.32 per cent from 2000-2019. The sewage line construction was observed as 47.80 per cent. The jet kings for sewage vehicles were observed as 12.44 per cent. As far as other services are concerned then CAGR for electricity bills was 11.88 per cent. The revenue expenditure on sewage line was 16.52 per cent.

\subsection{Capital Receipts of Municipal Corporation}

We have estimated the capital expenditure of the Thane municipal corporation from 2008-19. It is presented as follows

TABLE 3. CAPITAL RECEIPTS OF MUNICIPAL CORPORATION FROM 2008-19

\begin{tabular}{|c|c|c|c|}
\hline No & Items & Details & Percent \\
\hline 1. & General & General administrative services & 5.03 \\
\cline { 3 - 4 } & administration & Town planning & -3.00 \\
\hline \multirow{4}{*}{2.} & Fire brigade & -12.95 \\
\cline { 3 - 4 } & & Sports and culture & 6.07 \\
\cline { 3 - 4 } & \multirow{4}{*}{ Civic amenities } & Security deposit & 3.75 \\
\cline { 3 - 4 } & & Water supply tax & 14.48 \\
\cline { 3 - 4 } & & Water supply connection & 10.98 \\
\cline { 3 - 4 } & & Water theft & 27.91 \\
\cline { 3 - 4 } & & Pumping and licensing fees & 19.68 \\
\hline
\end{tabular}


Rode, S.

POPULATION GROWTH AND BOTTLENECKS IN PROVISION OF QUALITATIVE PUBLIC INFRASTRUCTURE SERVICES IN THANE MUNICIPAL CORPORATION

\begin{tabular}{|l|c|c|}
\hline \multirow{2}{*}{} & Tanker water supply & 10.09 \\
\cline { 2 - 3 } & Water supply related contract & 14.31 \\
\cline { 2 - 3 } & Contract fees & 2.16 \\
\hline
\end{tabular}

Source: Estimated from Thane Municipal Corporation budgets

The capital receipts of general administration were 5.03 per cent. The town planning related growth was negative (- 3 per cent). The fire brigade related capital expenditure was -12.95 per cent. The sports and culture related capital expenditure was 6.07 per cent. The capital receipts related water supply tax is observed as 14.48 per cent. The capital receipts from water supply connection were 10.98 per cent. The water theft related to capital receipts are observed as 27.91 per cent. The capital receipts through Pumping and licensing fees is observed as 19.68 per cent. The capita receipts from tanker water supply are observed as 10.09 per cent. The capital receipts are mainly comprising as the water supply tax. For pipelines in various societies, the road cutting work is done. The municipal corporation charge road cutting taxes. The tapping charges and plumbing license fees are also charged by the Thane Municipal Corporation. The plumbing fees are charged by the plumbers at various locations by corporation. The municipal corporation provides tanker water to various locations. It charges fees for water supply. The municipal corporation charges the water supply connection form fees. The regular tenders are issued in connection of water supply. The capital receipts through water supply related contract has increased as 14.31 per cent. The capital receipts related to contract fees is observed as 2.16 per cent. The Municipal corporation charges tender fees. The municipal corporation also charges the meter testing fees. The corporation also charges for the plumbing. The water leakages could be observed at various locations. The municipal corporation also put the fines on the unauthorized pipeline connection tax.

\subsection{Capital expenditure of Corporation}

We estimated the capital expenditure for the Thane Municipal Corporation over the period of time (2008-19). Following table shows the details.

TABLE 4. CAPITAL EXPENDITURE OF THANE MUNICIPAL CORPORATION (2008-19)

\begin{tabular}{|c|c|c|c|}
\hline No & Categories & Subheads & Percent \\
\hline 1 & General administration & Complaint solution & -8.83 \\
\hline 2 & Planning and regulation & Law department & 30.83 \\
\hline 3 & Public works & Vehicles & 14.79 \\
\hline & & Machines purchase & 51.54 \\
\cline { 3 - 4 } & & Pollution control board & 23.78 \\
\cline { 3 - 4 } & & Health department & 13.95 \\
\cline { 3 - 4 } & & CSM hospital & 19.33 \\
\cline { 3 - 4 } 4 & \multirow{3}{*}{4} & Hospitals and dispensaries & 16.60 \\
\cline { 3 - 4 } & Health & Health check-ups & 10.79 \\
\cline { 3 - 4 } & & & \\
\end{tabular}


Rode, $\mathrm{S}$.

POPULATION GROWTH AND BOTTLENECKS IN PROVISION OF QUALITATIVE PUBLIC INFRASTRUCTURE SERVICES IN THANE MUNICIPAL CORPORATION

\begin{tabular}{|c|c|c|c|}
\hline & \multirow{6}{*}{$\begin{array}{l}\text { Sanitation and solid waste } \\
\text { management }\end{array}$} & Birth and death department & 5.20 \\
\hline & & Malaria eradication & 14.24 \\
\hline & & National program on health & 23.01 \\
\hline \multirow{3}{*}{5} & & Solid waste & 13.80 \\
\hline & & Animal health & 14.06 \\
\hline & & Animal ponding & 12.25 \\
\hline \multirow{13}{*}{6} & \multirow{13}{*}{ Civic amenities } & Fire hydrants & 14.23 \\
\hline & & Markets & 2.41 \\
\hline & & Entertainment & 17.11 \\
\hline & & Water supply & 24.02 \\
\hline & & Water supply lines & 10.13 \\
\hline & & Construction pipeline drains & 8.02 \\
\hline & & Meter reading & 2.03 \\
\hline & & Water leakages and audit & 5.03 \\
\hline & & Rainwater collection & -7.21 \\
\hline & & Sewage & 2.70 \\
\hline & & Sewage line and chambers & 13.65 \\
\hline & & Gardens & 14.30 \\
\hline & & Dadoji Kondadev Stadium & 22.16 \\
\hline \multirow{3}{*}{7} & \multirow{3}{*}{ Social welfare } & Social development programs & 23.13 \\
\hline & & Social backward section & 16.91 \\
\hline & & Dalit vasti water supply & 6.10 \\
\hline \multirow{6}{*}{8} & \multirow{6}{*}{ Other services } & Computer section & 17.18 \\
\hline & & ICT & 15.23 \\
\hline & & Stationary & 13.30 \\
\hline & & Vehicles & 14.14 \\
\hline & & Education: integrated school development & 20.18 \\
\hline & & Jawahar rebirth scheme & 28.29 \\
\hline \multirow{4}{*}{10} & \multirow{4}{*}{ Revenue } & Audit section & 11.43 \\
\hline & & Accounting section & 12.34 \\
\hline & & Tax collection department & 13.28 \\
\hline & & Octroi & 3.07 \\
\hline
\end{tabular}

Source: Estimated from Thane Municipal Corporation budgets

Capital expenditure for complaint solving was -8.83 per cent during 2002-19. Now most of the complaints are made through internet. They are sent to ward offices. Therefore, they are solved in routine work. Therefore, the budget for complaint solving is reduced. For planning and regulation related capital expenditure specially law section was 30.83 per cent. Municipal Corporation is spending more money on law and order in city. For that purpose, more money is spent in Thane city. The vehicles related capital expenditure was 14.79 per cent. The machines purchase related capital expenditure was 51.54 per cent. As far as health of people is concerned in Thane city then the capital expenditure on pollution control board was 23.78 per cent. The capital expenditure on health department was 13.95 per cent. Municipal Corporation is spending more money on the health of people. The municipal corporation spends money for health care staff, hospital equipment and other equipment regularly. In Kausa 
hospital, the municipal corporation has purchased the equipment's. The municipal corporation has also built hospitals and dispensary buildings in various wards. The regular health check-ups of poor are done in various wards. The numbers of health care related vehicles are purchased. The capital expenditure on Chatrapati Shivaji Maharaja Hospital was 19.33 per cent. Many poor and middle-class people are visiting this hospital and taking health care. Municipal Corporation spends money on Chatrapti Shivaji Maharaja Hospital. Money is provided to buy various health care related equipment's and infrastructure. It also includes fire equipment's, furniture purchase, electric work, solar and air condition equipment's. Municipal Corporation already spent lot of money for Chatrapati Shivaji Maharaja Hospital. It mainly includes furniture, lab equipment's. Municipal Corporation also spends on Jim equipment's in hospital. The capital expenditure on hospitals and dispensaries was 16.60 per cent. Municipal Corporation is spending for various camps in corporation. The birth and death department has 5.20 per cent capital expenditure. The money is spent on computerization, printing and salary of people working in this department. The capital expenditure on Malaria eradication was 14.24 per cent. For malaria eradication various instruments, tablets are purchased. For national health programs, the money is spent. The growth of such expenditure was 23.01 per cent. The municipal corporation takes part in various national programs in health. The administrative help as well as money spent for pulse polio, AIDS control, RCH programs and Adult health programs in corporation area. As far as sanitation and solid waste management in city is concerned then the capital expenditure growth was 13.80 per cent. Municipal Corporation has ambitious earth worm project and it buys various equipment's for it. The capital expenditure on health of animals was observed as 14.06 per cent. The capital expenditure on animals ponding was 12.25 per cent from 2000-2019. As far as civic amenities are concerned then the growth of capital expenditure on fire hydrants was 14.23 per cent. Thane Municipal Corporation was spending more on the fire hydrants. The municipal corporation has purchased fire hydrants related vehicles. Thane Municipal Corporation also purchases other equipment's related to fire hydrants. The capital expenditure on entertainment was 17.11 per cent. Various theaters are built by corporation in city. The capital expenditure on water supply was 24.02 per cent. It is the responsibility of the corporation to provide 135 litter per capita drinking water to all people living in corporation area. The capital expenditure on water supply lines was 10.13 per cent. The municipal corporation has water supply expansion project in various wards and newly developed areas. It spends on building tanks, water supply lines, filtration plant and buildings. The municipal corporation also spends money on vehicle purchase. The water meters are purchase by corporation. The municipal corporation purchased the water leakage technology. It is doing audit regularly. The Dalit Vasti water supply connections are provided by corporation. There is renovation of wells in corporation area. The municipal corporation has 
Rode, $\mathrm{S}$.

POPULATION GROWTH AND BOTTLENECKS IN PROVISION OF QUALITATIVE PUBLIC INFRASTRUCTURE SERVICES IN THANE MUNICIPAL CORPORATION

planned $24^{\star} 7$ water supply schemes. The Municipal Corporation has purchased tank cleanliness machine.

The various water supply lines are put in corporation area. The capital expenditure on construction of pipeline drain was 8.02 per cent. The drainage line is very useful for sewage flow. Municipal Corporation is buying meters for water and electricity. The capital expenditure on meter buying was 2.03 per cent. For the water leakages and water audit, the capital expenditure was 5.03 per cent. Regular water leakages are solved in corporation area. The water audit reports were regularly available in corporation area. The capital expenditure on rainwater collection is observed as -7.21 per cent. It means that municipal corporation is not serious to store water through rain harvesting. Rainwater harvesting is not taken seriously in Thane city because high rainfall in city. The capital expenditure on sewage was observed as 2.70 per cent in corporation area. The sewage line and chambers related capital expenditure was 13.65 per cent. Municipal Corporation built toilet buildings in various wards and modern toilet building near highway. The sewage line is built in various wards by corporation. An emergency work is done at various wards. Municipal Corporation has built toilets for women. Municipal Corporation took part in India cleanliness drive under toilet building. It spent lot of money on toilets in city. The corporation has bought jetting vehicles for cleanliness. Municipal Corporation has decided to treat sewage and reuse of water for different purposes. It has also built septic tank in corporation area. The municipal corporation is regularly spending on the gardens. Such capital expenditure is observed as 14.30 per cent. Municipal Corporation has decided to develop gardens in city and beautify them. The municipal corporation has green Thane project. It has spent lot of money for it. In most of the gardens, the corporation is, fixing toys for small children. An electric work such as lightening, showers is done in gardens. The municipal corporation has developed Salim Ali environment Development Park. It has spent maximum money on it. The bird century development work is also going on in corporation area. The municipal corporation has developed the theme park. It is another development project in corporation area. The municipal corporation has developed Nana-Nani Park, Science Park, and Kalava Khadi Park. Lot of money spent on these park and development of these parks. The municipal corporation has developed nursery for tree plantation. Near the Thane creek, the corporation has decided to protect mangroves. It is protecting biodiversity and forest in its area. On Dadoji Kondev stadium, the capital expenditure was grown as 14.30 per cent over the period of time. Dadoji Kondev stadium has renovated many times. The municipal corporation has developed an indoor stadium building and for this work money is spent. The municipal corporation has renovated the Sachin Tendulkar Mini Stadium. The money is spent for it in various budgets. There are many grounds in corporation area and Municipal Corporation spent for ground development regularly. The money is 
spent on rapid net sports as well as shooting range preparation. The poverty alleviation and social welfare is concerned then social development program was 23.13 per cent. Municipal Corporation is spending on various welfare programs. The capital expenditure on social back ward section was 16.91 per cent. The capital expenditure on Dalit Vasti water supply was 6.10 per cent. The municipal corporation always gives the priority for Dalit vasti development in city. In in regular budgets of corporation, the money is spent on water supply schemes of Dalit Vasti. The municipal corporation spends money on child and women programs. Lot of money spent on slum related programs. The various programs are organized which are related to culture of city.

As far as other services are concerned then capital expenditure on computer section was 17.81 per cent. The capital expenditure on ICT was 15.23 per cent. The municipal corporation is spending on technology. The capital expenditure on stationary was 13.30 per cent. Municipal Corporation buys various types of stationary for various purposes each year. The capital expenditure on education and integration of school development was 20.18 per cent. Municipal Corporation runs various educational programs in their schools. For Jawahar rebirth scheme, the capital expenditure was 28.29 per cent. An accounting related capital expenditure was observed as 11.43 per cent. The auditing reports and auditing expenditure is done by the municipal corporation. Such expenditure growth was 12.34 per cent. The capital expenditure growth on tax collection department was 13.28 per cent. The municipal corporation collects the tax from various bodies. The municipal corporation refund the collected tax. The municipal corporation is spending money for administrative purposes. The money is spent on vehicles purchase. The municipal corporation is spending money for modernization of octroi collection centers. The octroi related capital expenditure is observed as 3.07 per cent. It is comparatively less as compare to other expenditure.

\section{LEAST SQUARE REGRESSION RESULTS}

We have used ordinary least square regression (Greene William, 2018) to study the relationship of different variables with the revenue receipts and expenditure, capital receipts and expenditure. The data for regression result is used as various budgets (2008-2019) of Thane Municipal Corporation. The regression model is defined as follows.

$Y_{i t}=\beta+x_{1} \beta_{1}+x_{2} \beta_{2}+x_{3} \beta_{3}+x_{4} \beta_{4}+\ldots \ldots \ldots \ldots+\epsilon$

Where

- $Y_{i t}$ considered as dependent variable of the data series

- $x_{1}$ is the independent variable categorized into different types 


\section{POPULATION GROWTH AND BOTTLENECKS IN PROVISION OF QUALITATIVE PUBLIC INFRASTRUCTURE SERVICES IN THANE MUNICIPAL CORPORATION}

- $e$ is an error term in equation

- $\beta_{2}$ is the variance of the error term

- $\beta_{1}$ means the intercept parameter or coefficient

- $\beta_{2}$ is the slope parameter or coefficient

- i stands for the ith observation in the data set, $\mathrm{i}=1,2, \ldots, \mathrm{N}$

- $N$ is the number of observations in the data set of study

In the above regression, the dependent variable is used as Thane Municipal Corporations every year's revenue receipts and expenditure. Same category is considered for capital receipts and expenditure. We have used various independent variables from each category of receipts and expenditure. However, every sub head category is regressed with specific regression. We have presented separate regression results for number of dependent variables.

TABLE 5. REGRESSION RESULT FOR REVENUE RECEIPTS OF MUNICIPAL CORPORATION

\begin{tabular}{|l|l|lll|}
\hline Variables & $\begin{array}{l}\text { Co-efficient (Standard } \\
\text { error) }\end{array}$ & T test & \\
\hline Solid waste management & $160.49^{* *}(66.79)$ & 2.40 & & \\
\hline Audit & $8.08^{*}(2.07)$ & 3.90 & & \\
\hline Constant & $283734.77^{*}(48416.66)$ & 5.86 & & \\
\hline $\mathrm{R}=0.97 \quad \mathrm{R} 2=0.95 \quad$ Ad & $\mathrm{F}=12.37^{*}$ & $\begin{array}{l}\text { Standard error of } \\
\text { estimate=547.48 }\end{array}$ & \\
$\mathrm{R}^{2}=0.93$ & &
\end{tabular}

Source: Author

The revenue receipts for Thane Municipal Corporation are positively co-related and statistically significant with solid waste related receipts. The municipal corporation put solid waste collection charge on big housing projects in city. The municipal corporation spends more money on cleanliness of city. It also receives various funds from center and state government. Thane Municipal Corporation spends more money on the audit of corporation. It is the positive co-related and statistically significant with revenue receipts of Thane Municipal Corporation.

TABLE 6. REGRESSION RESULT FOR CAPITAL RECEIPTS OF CORPORATION

\begin{tabular}{|l|l|l|}
\hline \multicolumn{1}{|c|}{ Variables } & \multicolumn{1}{|c|}{$\begin{array}{c}\text { Co-efficient } \\
\text { (Standard error) }\end{array}$} & \multicolumn{1}{|c|}{ T test } \\
\hline Water tariff & $2.64^{*}(0.08)$ & 33.27 \\
\hline Water supply connection & $1.52^{* *}(0.47)$ & 3.26 \\
\hline Tanker water supply & $21.76^{\star *}(6.25)$ & 3.48 \\
\hline Constant & $1583.13^{*}(359.38)$ & 4.40 \\
\hline $\mathrm{R}=0.99 \mathrm{R} 2=0.99 \mathrm{Ad} \mathrm{R}^{2}=99$ & $\mathrm{~F}=582.37^{*}$ & $\begin{array}{l}\text { Standard error of the } \\
\text { estimate=321.86 }\end{array}$ \\
\hline
\end{tabular}

Source: Author 


\section{POPULATION GROWTH AND BOTTLENECKS IN PROVISION OF QUALITATIVE PUBLIC INFRASTRUCTURE SERVICES IN THANE MUNICIPAL CORPORATION}

The water tariff of Thane Municipal Corporation is positively co-related to the capital receipts. Thane Municipal Corporation charges high water tariff on water use. Such tariff is regularly revised from time to time. The water supply connections are positively co-related to capital receipts. It is because Thane Municipal Corporation charges for water supply connections. The capital receipts are positively corelated to tanker water supply. Most of the time municipal corporation provides the water through tankers. Municipal Corporation charges very high for tanker water supply. Therefore, it is positively corelated and statistically significant.

TABLE 7. THE LEAST SQUARE REGRESSION RESULT FOR CORPORATION'S REVENUE EXPENDITURE
\begin{tabular}{|l|l|l|}
\hline \multicolumn{1}{|c|}{ Variables } & $\begin{array}{c}\text { Co-efficient } \\
\text { (Standard error })\end{array}$ & \multicolumn{1}{|c|}{ T test $^{*}$} \\
\hline Fuel expenditure & $686.31^{* *}(74.63)$ & 9.19 \\
\hline $\begin{array}{l}\text { Maintenance and care of water supply } \\
\text { pipe line }\end{array}$ & $3.58^{*}(0.72)$ & 4.98 \\
\hline Sewage & $-266.95^{* *}(63.54)$ & -4.20 \\
\hline Tax and rent of buildings & $498.57^{* *}(106.21)$ & 4.69 \\
\hline Constant & $6978.80^{* *}(950.38)$ & 7.34 \\
\hline $\mathrm{R}=0.99 \mathrm{R} 2=0.99 \mathrm{Ad} \mathrm{R}^{2}=0.98$ & $\mathrm{~F}=107.26^{*}$ & $\begin{array}{l}\text { Standard error of the } \\
\text { estimate }=767.32\end{array}$ \\
\hline
\end{tabular}

Source: Author

In Thane Municipal Corporation, the fuel related expenditure is positively co-related and statistically significant with revenue expenditure. Maintenance and care of different water supply lines in Thane Municipal Corporation area is positively co-related to revenue expenditure. Water supply pipelines are very old and there are always leakages observed with pipelines. There is no choice with the corporation but to repair the pipelines immediately and save the water. The sewage related expenditure is negatively correlated and significant to capital receipts in Thane Municipal Corporation. The capital receipts are positive and statistically co-related to the tax and rent of the building. Municipal Corporation gets the rent from the various buildings. However, it spends for the maintenance of the building also.

TABLE 8. REGRESSION RESULT FOR CAPITAL EXPENDITURE OF THANE MUNICIPAL CORPORATION

\begin{tabular}{|l|l|ll|}
\hline \multicolumn{1}{|c|}{$\begin{array}{c}\text { Capital Expenditure related } \\
\text { variables }\end{array}$} & \multicolumn{1}{|c|}{$\begin{array}{c}\text { Co-efficient } \\
\text { (Standard error) }\end{array}$} & \multicolumn{2}{|c|}{ T test } \\
\hline Dalit vasti water supply & $543.46^{\star \star}(200.14)$ & 2.71 \\
\hline MHADA colony & $-101.72^{* \star}(42.00)$ & -2.42 & \\
\hline Water supply & $140.87(73.76)$ & 1.91 & \\
\hline Solid waste expenditure & $86.71(58.20)$ & 1.49 & \\
\hline Constant & $283734.77^{*}(48416.66)$ & 5.86 & \\
\hline $\mathrm{R}=0.89 \mathrm{R}^{2}=0.79 \mathrm{Ad} \mathrm{R}^{2}=0.59$ & $\mathrm{~F}=13.91^{* *}$ & $\begin{array}{l}\text { Standard error of } \\
\text { estimate=10263.36 }\end{array}$ & \\
\hline
\end{tabular}

Source: Author 
Rode, $\mathrm{S}$.

POPULATION GROWTH AND BOTTLENECKS IN PROVISION OF QUALITATIVE PUBLIC INFRASTRUCTURE SERVICES IN THANE MUNICIPAL CORPORATION

The Dalit vasti water supply is positively co-related to the capital expenditure. It is positive because Municipal Corporation spends more on such welfare scheme. The capital expenditure on MHADA Colony was negatively co-related with capital expenditure. The capital expenditure through water supply is positively co-related. It is statistically significant. The capital expenditure on the solid waste expenditure is positively co-related and statically significant. Segregation and storage at source was lacking and the decomposable and non-decomposable wastes are disposed of at common communal bins. Later, waste from these bins is transported to landfill sites for dumping by Municipal Corporation. Due to poor knowledge, insufficient number of bins and apathy towards this cause, households often tip their waste on vacant lands and/or streets. Due to limited number of waste workers, it was difficult for the SMC to pick up waste from the streets. Private waste collectors also collect waste from households in a few localities. However, they are interested only in dry recyclable waste, which they sell to earn revenue, leaving organic and non-recyclable material in neighboring street corners, vacant plots and community bins. Thus, overflowing garbage bins, foul smells emanating from dumps and unprocessed waste at landfill caused several environmental risks. More than the willingness of SMC, the absence of an alternate model was perhaps a major deterrent in tackling this issue (Mohana et al., 2016).

\section{CONCLUSION AND POLICY IMPLICATION}

Thane Municipal Corporation finds difficulties in provision of civic services to its population. Due to excessive migration, population density is increasing very fast. Population growth resulted into inadequate, inconsistent civic infrastructure services. The budget is low to appoint staff, purchase of various instruments. The transport for people, purchase of water meters and pipes, sewage pipes, vehicles for solid waste, segregation of solid waste and dumping ground related issues are observed. Therefore, numbers of policies are required to solve the various issues in corporation area. An analysis suggests that participation is indeed likely to increase when a service is decentralized because it must compete with fewer other issue areas for voter and politician attention. This being said, citizen mobilization is likely to focus on preventing tariff increases and service cut-offs which constitute concrete, short-run losses for consumers rather than on encouraging investments in longer term projects that may not yield the benefits politicians promise with certainty (Herrera and Post, 2014) We found that bus depots are limited in Thane city. City planners should consider the need for depots in land use planning and zoning. The city governments should develop new governance models of the depots together with real estate investors to promote the easy entries and exits of buses (Valkama et al., 2018). The budget allocation for sewage facilities must be increased. The solid waste must be collected all over the city. Solid Waste Management is the need of the hour in corporation area. It 
should be taken seriously by civic body. Public apathy and cooperation by the municipal corporation is a great hurdle in solving this problem. Municipal corporation should pass few laws for collection, disposal and treatment of solid waste. Municipal corporation should not give non objection certificates to residential, commercial buildings until they provide the disposal and treatment of its own waste. In Thane Municipal Corporation, there is a strong case of private sector participation and private sector can come with its expertise, technology and capital, improved and efficiently managed service. Public participation is of paramount importance and can provide big results if seek properly (Vij, 2012). Municipal solid waste has emerged as a big challenge not only because of the health and environmental concerns but also due to huge quantities of waste generated. It is observed from many research documents that most urban local bodies are unable to handle such huge quantities of solid waste due to financial and institutional debilities. Segregation of waste, door to door waste collection, technologies for the treatment of waste, land resources and scientific disposal methods are some of the major challenges (Vassanadumrongdee and Kittipongvises, 2018). The Thane Municipal Corporation should focus on complete coverage of sanitation facility. Sanitation must be provided to every household on a sustainable manner in corporation area. Combining the people's opinion of their need and experts thinking is the core idea of participatory city planning. Sanitation is one of those facilities that need to be provided in the slum area in an equal manner (Alam and Mondal, 2018). More money should be sanctioned for systematic and planned development of Thane city. In order to bring the universality, comparability and ranking of services across geographical areas, there are number of methods used and developed for city infrastructure and cleanliness. Such methods can be helpful for researchers and decision makers, being useful as an assessment procedure (Biswas et al., 2018). City administration should collect more data and prepare maps for effective planning for city (Devulapalli and Agrawal, 2017). Such policies will help Municipal Corporation to work effectively for its people and collect more revenue for further development of city.

\section{REFERENCES}

Alam, Md. S. and Mili Mondal (2018). 'Assessment of sanitation service quality in urban slums of Khulna city based on SERVQUAL and AHP model: A case study of railway slum, Khulna, Bangladesh' Journal of Urban Management, Vol.8 (4):1-12.

Baidyaa, Rahul, Biswajit Debnathb, Debashre Dec and Sadhan Kumar Ghosh (2016). 'Sustainability of modern scientific waste compacting stations in the city of Kolkata' Procedia Environmental Sciences, Vol.31 (2016) 520 - 529.

Biswas R Rathin, Arnab Jana, Kavi Arya, Krithi Ramamritham (2018). 'A good-governance framework for urban management' Journal of Urban Management, Vol.7(2):1-12. 


\section{POPULATION GROWTH AND BOTTLENECKS IN PROVISION OF QUALITATIVE PUBLIC INFRASTRUCTURE SERVICES IN THANE MUNICIPAL CORPORATION}

Devulapalli Harsha and Girish Agrawal (2017). 'Mapping bus transit services in Hyderabad - an illustrative example of the use of open geospatial data' Transportation Research Procedia, Vol. 25 (2017) 4196-4206.

Ghosh A. and Kanika Kalra (2016). 'Institutional and financial strengthening of intermediate public transport services in Indian cities' Transportation Research Procedia, Vol. 14 ( 2016 ) 263 - 272.

Govinda Rao M. (2017) 'Public Finance in India in the Context of India's Development' NIPFP Working paper series, Working Paper No. 219. 28-Dec-2017.

Greene William H. (2018) 'Econometric analysis' $8^{\text {th }}$ Edition, Pearson publication Private Limited, Indian branch, Delhi, India.

Guite L.T. S. (2017). 'Assessment of urban sprawl in Bathinda city, India' Journal of Urban Management, Vol. 30 (15): 1-11.

Herrera Veronica and Alison E. Post (2014) 'Can Developing Countries Both Decentralize and Depoliticize Urban Water Services? Evaluating the Legacy of the 1990s Reform Wave' World Development, Vol. 64(1):621-641, 2014.

Jouhara, H., D. Czajczynska, H. Ghazal, R. Krzyzynska , L. Anguilano, A.J. Reynolds, N.Spencer (2017) 'Municipal waste management systems for domestic use' Energy' Vol.139 (2):485-506.

Khatua, Sarani (2019) 'Municipal finance of suburban Municipalities-Kolkata Metropolitan area' International Journal of Social Science and Economic Research, Vol.04(03):1646-1662.

Mohana,, Giresh, Ujjawal Kumar Sinhab, Meva Lalc(2016) 'Managing of Solid Waste through Public Private Partnership Model' Procedia Environmental Sciences, Vol.35 (2):158 - 168.

Nena Sonal (2014) 'An Empirical Study on Financial Performance of Corporations of Gujarat State' International Journal of Advance Research in Computer Science and Management Studies, Vol.2(1):18-26, January 2014.

Shyamala Mani, Satpal Singh (2016) 'Sustainable Municipal Solid Waste Management in India: A Policy Agenda' Procedia Environmental Sciences Vol.35(1):150-157.

Siddaram.R, and H. H. Bharadi (2017) 'Financial performance of municipal finance in Karnataka: A case Studies of Hubli-Dharwad Municipal Corporation' Review of Research Monthly Multidisciplinary, Vol.7(1):1-8, October 2017.

Subrina, S. and Farahnaz Khadiza Chowdhury (2018). 'Urban Dynamics: An undervalued issue for water logging disaster risk management in case of Dhaka city, Bangladesh' Procedia Engineering Vol.212 (2):801-808.

Szarowská Irena (2016). 'Quality of public finance and economic growth in the Czech Republic' ACTA Universities Agriculture ET SIL Viculturae Mendlianae Brunensis' Vol. 64(4):1373-1381, 2016.

Valkama, Pekka, Jari Kankaanpaa, Ari-Veikko Anttiroiko (2018). 'Financial and structural impacts of quasi-marketization of the Helsinki Metropolitan Area's bus services' Case Studies on Transport Policy, Vol.6 (2):246-256.

Varghesea Varun and Bhargav Adhvaryua (2016). 'Measuring overcrowding in Ahmedabad buses: costs and policy implications' Transportation Research Procedia, Vol.17:145-154.

Vassanadumrongdee, Sujitra and Suthirat Kittipongvises (2018). 'Factors influencing source separation intention and willingness to pay for improving waste management in Bangkok, Thailand' Sustainable Environment Research, Vol. 28 (2): 90-99. 
Rode, S.

POPULATION GROWTH AND BOTTLENECKS IN PROVISION OF QUALITATIVE PUBLIC INFRASTRUCTURE SERVICES IN THANE MUNICIPAL CORPORATION

Verma R.L., Borongana, G., M. Memonb (2016). 'Municipal Solid Waste Management in Ho Chi Minh City, Viet Nam, Current Practices and Future Recommendation Procedia Environmental Sciences, Vol.35:127-139.

Vij, Dimpal (2012). 'Urbanization and solid waste management in India: Present practices and future challenges' Procedia - Social and Behavioral Sciences, Vol.37(2):437- 447. 